\title{
BIRDS
}

\section{BIENNIAL REDPOLL INVASIONS}

C. STUART HOUSTON and MARY I. HOUSTON, 863 University Drive, Saskatoon SK S7N 0J8, and ALAN R. SMITH, Canadian Wildlife Service, 115 Perimeter Drive, Saskatoon SK

Redpolls invaded Saskatoon in unprecedented numbers during the first three months of the year 2000. Arguably, this was the most talked-about bird event of the year, particularly among members of the general public. Some days the Houstons' telephone rang repeatedly, with casual feeder-watchers asking the name of the little birds, often adding that these were a species they had not seen in previous winters. Almost without exception, those with feeders reported 20 to 40 redpolls visiting daily. Ninety-year-old Mary Mclntyre had over 50 at 410 Willow Street. Pat and Don Adams had up to 100, and saw their last redpoll of the season on March 31 .

Everyone agreed that redpoll numbers were greater than ever before, but this was anecdotal information. We asked ourselves: How many redpolls were present? How long did they stay in Saskatoon? How widely were banded birds distributed within the city? How widespread was this year 2000 redpoll irruption throughout the prairie provinces and how did this compare with previous years? How precise is the biennial nature of these movements? What percentage were Hoary Redpolls?

Our banding efforts this winter and previous winters provided our main source of information, which we supplemented by a review of Saskatoon Christmas Bird Counts since 1955. As confirmation of the biennial nature of redpoll visits to western Canada, we reviewed the prodigious redpoll banding record of Leroy and Myrtle Simmons of Winnipeg, 1964-1976.5 For evidence of the widespread distribution, we looked at the Great Backyard Bird Count on the Bird Source 2000 web site on the Internet. ${ }^{2}$

\section{Previous evidence for biennial irruptive migrations}

Two papers in 1976, one by Kennard using bird banding data, and the other by Bock and Lepthien using Christmas Bird Count data, independently reported that redpoll migrations are strikingly biennial. ${ }^{1,6}$ In 1983, Troy reviewed redpoll movements shown by banding records between 1923 and 1978, and found that banded birds returned to southern banding stations predominantly at two and four years after banding, but presumably did not move into settled areas in the intervening years. ${ }^{8}$ Troy's map, based on 106 recoveries from a winter subsequent to banding, showed a movement from the northwest, mainly Alaska, to the southeast, as far as the New England states.

These three papers, along with Hochachka et al. ${ }^{3}$ who used FeederWatch records to analyze the major irruptive migration of 1993-94, indicate that redpoll irruptions are evident in the last two weeks of oddnumbered years, and intensify in the first months of even-numbered years. Bock and Lepthien found "a general but not complete synchrony" with seven other species of boreal forest birds: Evening 
and Pine grosbeaks, Red and Whitewinged crossbills, Purple Finch, Pine Siskin, and Red-breasted Nuthatch. ${ }^{1}$ They postulated that the driving factor for these irruptions is the biennial variation in conifer cone crops and birch seed production, and reported "superflights" of a massive extent in 1935-36, and 1969-70. Kennard found that redpolls arrested their migration wherever they found heavy supplies of Yellow Birch seeds, yet the birch cycle occurred every three or four years and hence was not strictly biennial. ${ }^{6}$ Hochachka et al. admit that we still do not know whether the ultimate cause of irruptive migrations is high seed production causing northern retention of high redpoll populations, or low seed production causing massive emigration from the northern breeding grounds. ${ }^{3}$

\section{Bird banding in Winnipeg, 1964-1976}

Leroy and Myrtle Simmons banded a prodigious 22,504 Common Redpolls in their yard on the Seine River in Winnipeg between 1964 and 1978. ${ }^{5}$ With the exception of 1969 , when numbers were building up to the unusually large redpoll invasion early in 1970 , redpoll bandings were almost exclusively in even years (Fig. 1).

\section{Bird banding in Saskatoon, 1964 - 2000}

Although redpolls occur every winter in rural areas adjacent to Saskatoon, their appearance at the Houstons' backyard banding station at 863 University Drive has been confined only to even years - with one exception, the aberrant year of 1969 (Fig. 2). The number banded during 13 even years was 2235 and during 1969 was 104.

Year 2000 was the most exceptional even year to date. Between January 5 and March 20,2000, Stuart (CSH) and Mary (MIH) banded (right leg) 1438 Common Redpolls at 863 University Drive, using McCamey Chickadee traps.

Figure 1. Common Redpoll (CORE) banding at Winnipeg

\section{CORE banding at Winnipeg}

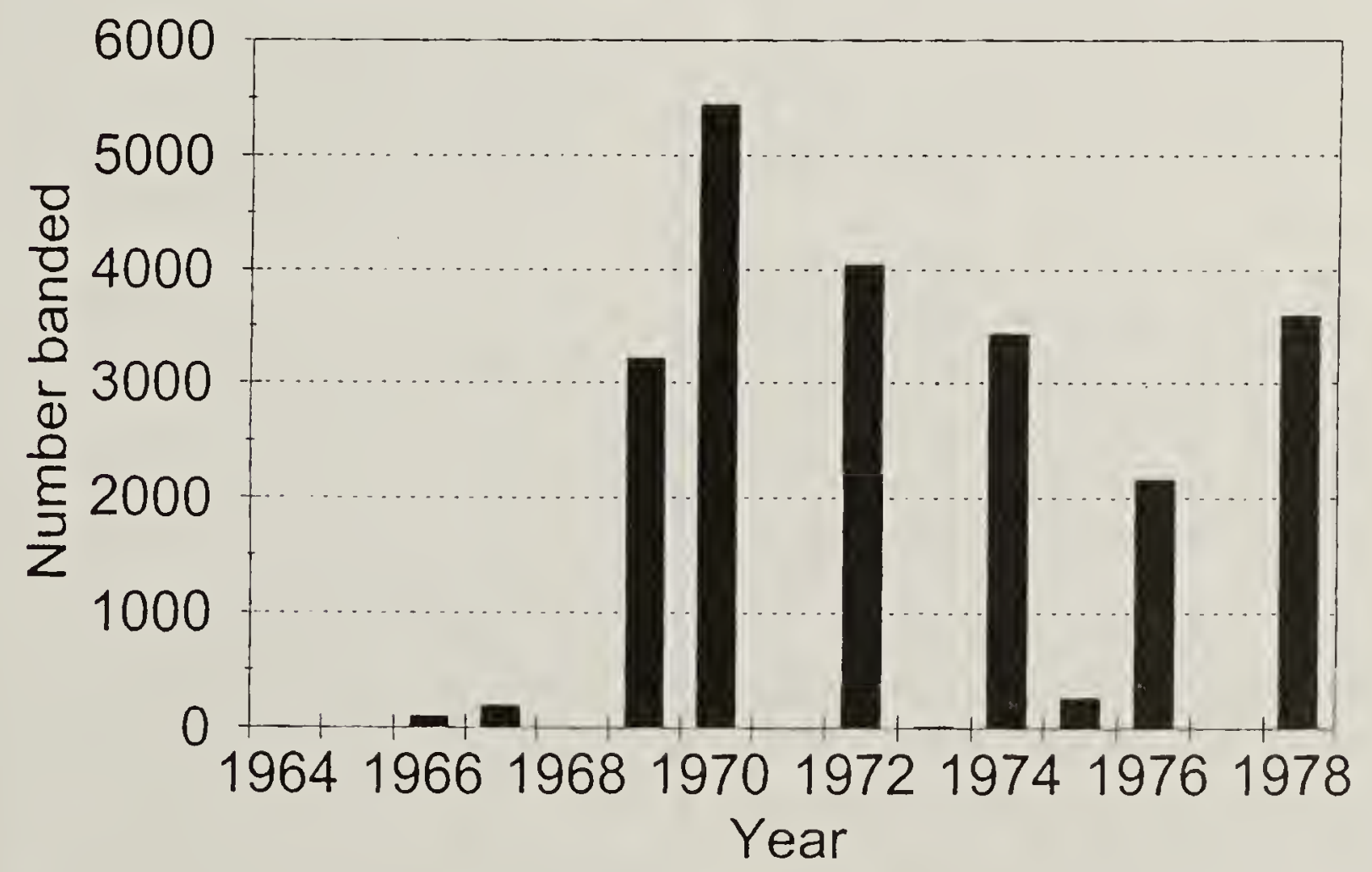




\section{Banding at Saskatoon}

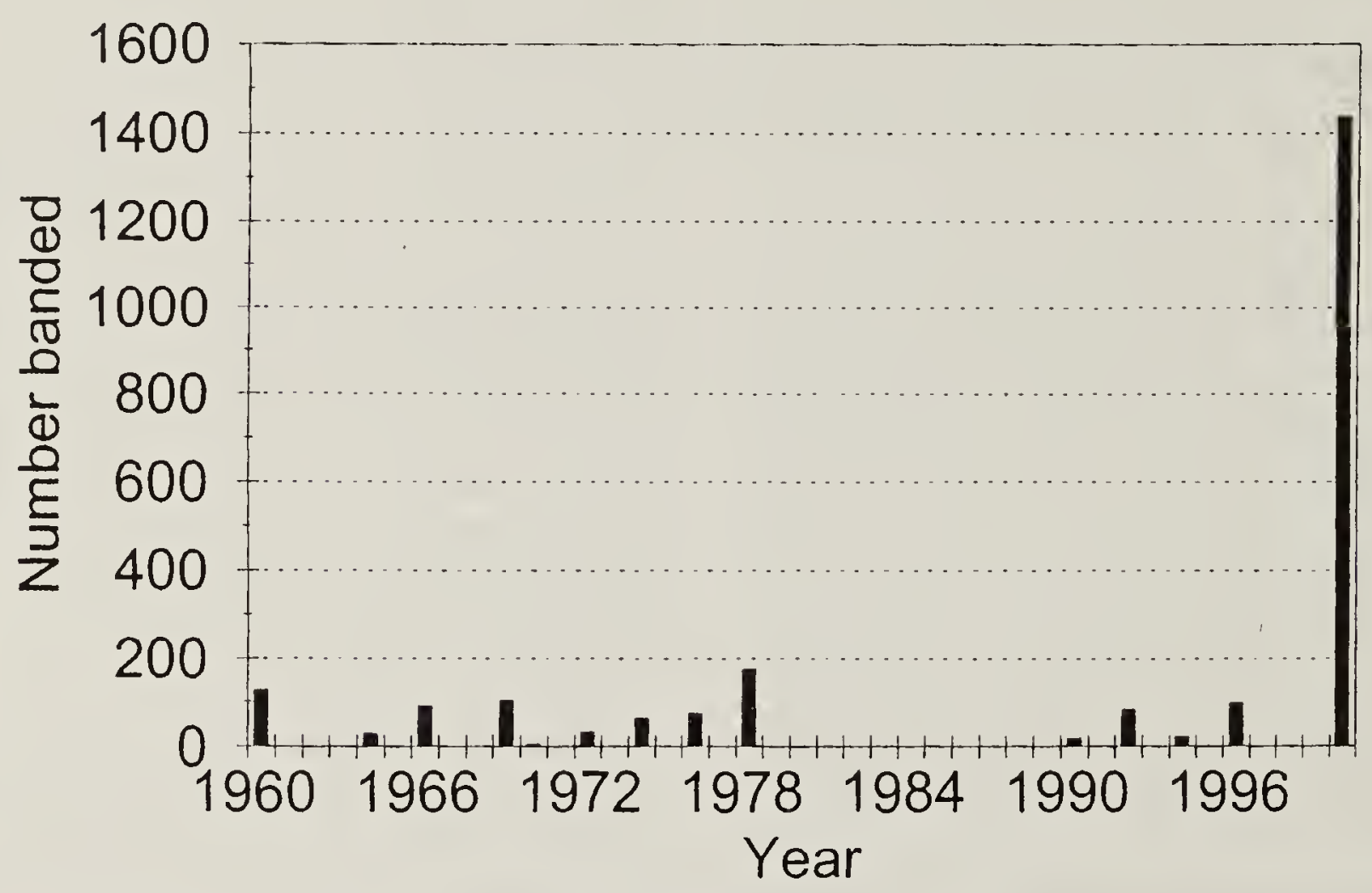

When the bird steps on a treadle to obtain niger seed, the door drops down. Sunflower seeds were also available, but the niger seed was the main attraction. (Only $9 \mathrm{~kg}$ of niger seed was used.)

The Houstons retrapped 183 individuals from 1 to 13 times, for a total of 251 retraps. Some of the redpolls banded in early January stayed well into March, e.g. one banded on January 8 was retrapped on March 15. We also caught two of Al Smith's redpolls, one at our banding station, $3.2 \mathrm{~km}$ distant from Al Smith's, and another when we left traps for one day at $P$ at and Don Adams, $0.6 \mathrm{~km}$ distant, to determine the origin of birds banded on the left leg.

Between February 1 and March 15, AI Smith banded (left leg) 154 redpolls in his yard at 318113 rd St.West. He had 36 recaptures of 24 individual banded redpolls and caught 3 of the 1438 banded by $\mathrm{CSH}$ and $\mathrm{MIH}$.
Perhaps the first portent of the massive redpoll invasion of the forthcoming winter was the sighting of an estimated 75,000 Common Redpolls passing through Sheep River Valley, in the foothills west of Turner Valley, Alberta.

W. Smith and R. Wershler sighted them before a blizzard on 31 October 1999.

(R. F. Koes and P. Taylor, Prairie Provinces Fall Migration, North American Birds 54:65-66, 2000). 
Figure 4. Common Redpoll numbers from Saskatoon Christmas Bird Counts (CBCs)

\section{Common Redpolls, CBC}

\section{Saskatoon}

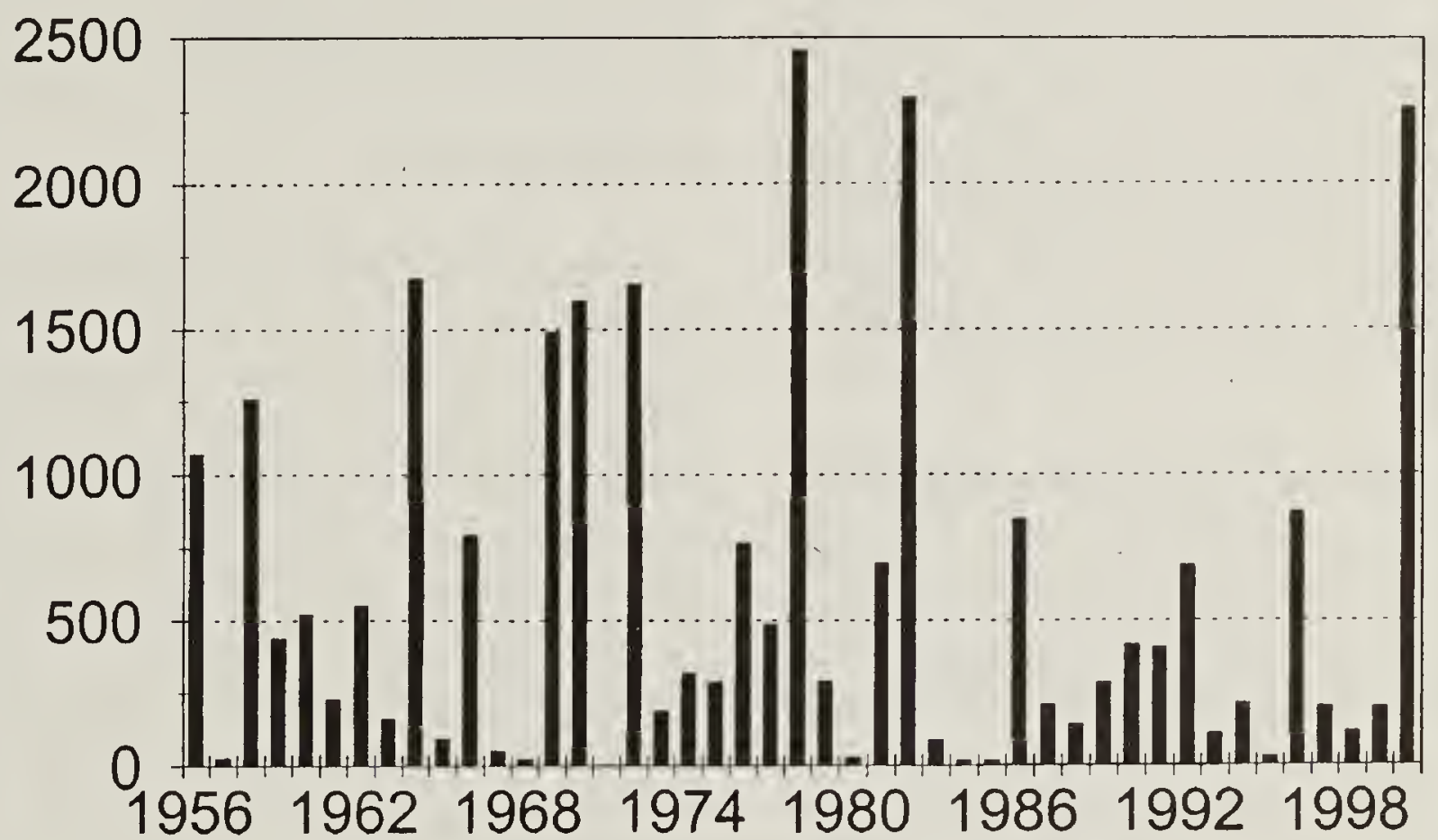

Wisconsin (707). Redpolls were also seen at more feeding stations than any other species in Newfoundland and were in second place in Yukon Territory, NorthWest Territories including Nunavut, and in North Dakota. In total numbers of individuals, however, Common Redpolls were first in the preceding four jurisdictions and also in Alaska, Quebec, New Brunswick, Prince Edward Island, Vermont, New Hampshire and Maine.

\section{Miscellaneous}

Leland Greenfield reported from Nokomis, SK on January 21 , that he had more redpolls than ever before at his feeder, with five visiting each minute. He had already fed them $135 \mathrm{~kg}$ of sunflower seed. A few of his redpolls died; a necropsy at the University of Saskatchewan revealed that salmonellosis was the cause of death. Dennis Fisher also submitted a specimen that proved to have peritonitis caused by Salmonella. No diseased birds were detected at the banding stations in Saskatoon.

Proof of the widespread nature of the irruption is evident from the banding of 2576 Common Redpolls, mostly in March, by the Timiskaming Banding Group in extreme eastern Ontario. ${ }^{7}$ One redpoll was resident there for 2 months and 23 days.

\section{Discussion:}

How many redpolls were present in Saskatoon in the year 2000?

Banding sampled 1592 individuals. These bands on redpolls then became a marker that allowed at least a rough "ball-park" assessment of the number of redpolls, certainly with more confidence than if none carried bands. It appears there was a loose agglomeration of redpolls throughout the city, consisting of sub-flocks moving from feeder to feeder. Before making a 
numerical estimation, several assumptions are necessary. One can reasonably assume that sightings of banded birds were birds banded in Saskatoon the same season. Second, this is not a closed population, but a constantly changing one, with redpolls coming in and others leaving. Third, the presence of numerous bird feeders (though the number is unknown) distributed unevenly throughout the various neighbourhoods, could artificially attract and maintain populations for a longer term than would occur in an unmanaged natural system.

Next, one must appreciate that if there was constant or extensive movement of redpolls into and out of the city, any calculation of a city-wide population of redpolls at a given time would result in a low estimate. On the other hand, if there were three or four large flocks that did not mix at all, in different corners of Saskatoon, the estimate would be high. These two influences might tend in the direction of cancelling each other.

One can then use the data from each banding station. The first method is to calculate a modified Lincoln Index - the number recaptured divided by the total number banded. For University Drive this is 183 divided by 1438 , or $12.7 \%$ of the total, which would have been 11,322 . This is the lowest population estimate from the various methods used. Smith's mist-netting showed recaptures of 24 birds, or $15.6 \%$. These figures depend to a large degree on duration of effort, since recaptures increase with time.

Next one must consider sightings of banded birds at other feeding stations in the city. The highest daily number of banded birds seen at a feeder distant from the banding stations was between 1 and 4 in a flock of 100 at the Adams' feeders, which would give a multiplicative factor of $100(100 \div 1)$ or
$25(100 \div 4)$. If 4 per 100 were an approximate sampling of the city flock, we could use 25 as a conservative multiplicative factor and say that the city population of redpolls must have been 25 times the combined total of birds banded by Houstons and Smith (1592), or at least 40,000 redpolls. If 1 per 100 was accepted as a sample number, then $100 \times 1592$ would mean a flock of over 150,000 redpolls.

Some Saskatoon feeders were against a window and allowed favourable conditions for seeing a band when present - yet at some, in spite of many hours of observation under ideal conditions over two months, no band was observed. Most of the remaining feeders had only one sighting of one banded bird within a flock of 30 to 50 . For these feeders combined, one might assign for an average day a multiplicative factor of at least 50 (i.e. $50 \div 1$ ) which when multiplied by 1592 is roughly 75,000 redpolls.

It would be imprudent, because of the small numerators involved, to derive a population figure from the Houstons' sample on University Drive of the birds Al Smith banded $3.5 \mathrm{~km}$ away. However, for argument's sake, if the Houstons' one recapture of the 156 redpolls banded by Smith, could by any stretch of the imagination be considered a representative sampling of the flock, it would mean a multiplicative factor of 150 , and thus a total count of 235,000 birds. Smith's sample of Houston banded birds (3/1438) would provide a an even higher and less credible factor of about 480 , and a population reaching as high as 750,000 .

With due cognizance of the caveat concerning the percentage of redpolls remaining in the city at a given time, we would nonetheless offer from the banding data a best-guess estimate of 
between 40,000 and 150,000 redpolls having visited Saskatoon, even if not all were present at once. More extreme numbers range from 11,000 to 750,000 redpolls. Perhaps the next irruption of this magnitude won't come for another 30 years, but if it does, recruitment of another ten banding stations would help hone these methods of estimation.

\section{Redpoll occurrence in Saskatoon in the year 2000.}

Redpolls were present at feeders in the city for roughly three months, from January 5 through March 31 . The longest interval between trappings of an individual was January 8 to March 15 , 67 days. Of redpolls banded through January 25 , there were retrappings of four birds at 48 days, two at 51 , two at 52 , one at 54 , two at 55 days, and one at 56 days. Of course we have no way of knowing how representative such long stays were among other members of the flock that were not retrapped, nor to what extent these particular individuals had become dependent on the University Drive feeding station.

Banded redpolls were sighted at 11
Saskatoon feeders, between 0.6 and 6.6 $\mathrm{km}$ from the banding site. Not one was sighted west of the central city core. In addition, two of Smith's redpolls may have been present at a farm $40 \mathrm{~km}$ south of Saskatoon.

$\mathrm{CSH}$ and $\mathrm{MIH}$ banded a total of five redpolls of the rostrata subspecies, with a noticeably larger body and a more massive beak, almost reminiscent of that of a grosbeak: two on January 8, two on February 1 and one on February 4. Al Smith captured one on February 19.

Although some birders, including $\mathrm{J}$. Frank Roy, have worried that some observers over-diagnose Hoary Redpolls in mixed flocks on Christmas Bird Counts, our figures suggest otherwise. Observers here list the very pale redpolls with white rumps (not necessarily immaculate white) and pure white undertail coverts, ${ }^{4}$ as Hoary Redpolls. All other redpolls are presumed and counted as Common Redpolls, even when a good look is not obtained; rarely is a flock classified as "unknown redpoll species." The Saskatoon CBC, 1955-1999, gave 1.3\%




as Hoary Redpolls. Saskatoon banding, 1964-1999, showed $1.3 \%$ of redpolls were Hoary Redpolls. During the recent irruption in the year 2000, Al Smith had $2 / 156$ or $1.3 \%$ Hoary Redpolls, but in a larger sample (the Houstons' banded birds) the percentage dropped to $11 /$ 1449 or $0.8 \%$.

The percentages of redpoll species over years of Christmas counts, and those examined in the hand by banders, give some credence to the ability of $\mathrm{CBC}$ counters to reach a correct diagnosis. There are no doubt regional differences. The Simmons in Winnipeg, 1964-1978, had a higher percentage $(830 / 23,334)$, of $3.6 \%$ Hoary Redpolls.

\section{Conclusion}

In Saskatchewan and Manitoba, every year since records have been kept (except 1969), redpolls have appeared in high numbers at city feeders in January and February, only in even-numbered years. The birch seed crop is mainly but inconsistently biennial. ${ }^{1,6}$ Our best guess, chosen from the two possibilities offered by Hochachka et al., is that the low seed productivity hypothesis predominates, as follows. When Dwarf Birch, Betula glandulosa, on the redpoll breeding grounds of arctic tundra, produces few or no seeds, the redpolls begin an irruptive migration to the south and east, the extent depending on how severe the seed failure is. In alternate years, however, when birch produce massive amounts of seeds, most redpolls winter farther north, although sometimes spread short distances south to consume seeds of other Betula species as necessary. Their southward movement usually stops when and wherever sufficient birch seeds are encountered. The few redpolls that reach settled areas in such oddnumbered years, tend to spend the winter in rural areas, and rarely appear at feeders within the city.
Without question, these movements in North America adhere remarkably to a precise two year schedule, perhaps more so than most other cyclical phenomena in nature. Although the monitoring methods of amateur observers are sufficiently inconsistent to preclude absolute certainty, the winter of 19992000 may have been the most extensive of these irruptions ever recorded.

\section{Acknowledgements}

We thank Donald S. Houston for statistical analysis.

1. Bock, C.E., and L.W. Lepthien. 1976. Synchronous eruptions of boreal seedeating birds. American Naturalist 110:559-571.

2. Great Backyard Bird Count, Feb. 1821, 2000. <http://www.birdsource.org/ gbbc/index.html>

3. Hochachka, W.M., J.V. Wells, K.V. Rosenberg, D.L. Tessaglia-Hymes, and A.A. Dhont. 1999. Irruptive migration of Common Redpolls. Condor 101:195204.

4. Houston, C.S. 1963. Redpoll identification - a problem. Bird-Banding 34:94-95.

5. Houston, C.S., and M.I. Houston. 1998. Leroy and Myrtle Simmons, record-breaking Winnipeg banders. Blue Jay 56:75-81.

6. Kennard, J.H. 1976. A biennial rhythm in the winter distribution of the Common Redpoll. Bird-banding 47:231-237.

7. Kinch, B. 2000. Redpolls at Mountain Chutes Camp. OBBA Newsletter 45(2):6-7.

8. Troy, D. 1983. Recaptures of redpolls: movements of an irruptive species. Journal of Field Ornithology. 54:146-151. 